\title{
PERFORMANCE ANALYSIS OF CONVENTIONAL LPG COOKING STOVE
}

\author{
Pulkit Agarwal. ${ }^{1}$, Abhishek Anand. ${ }^{2}$, Rajesh Gupta. ${ }^{3}$ \\ 1,2Under graduate Scholar, M.A.N.I.T, Bhopal, India \\ 3M.A.N.I.T, Bhopal, India \\ Email: 1pulkit.suresuccess@gmail.com
}

\section{ABSTRACT}

This study involves performance analysis of Conventional LPG Cooking Stove. A Conventional LPG burner is taken to carry out a series of experiments. Thermal efficiency of LPG burner is measured for a wide range of parameters such as loading height, pot diameter, and loading weight. The maximum thermal efficiency of $61.66 \%$ could be achieved with the present burner. Emission levels for species namely $\mathrm{CO}, \mathrm{CO}_{2}$, and $\mathrm{NO}_{x}$ are measured at different power levels. The maximum $\mathrm{NO}_{x}$ emission level for this burner is around $49 \mathrm{ppm}$. The experimental method was carried out using water boiling test and emission test according to IS 4246:2002 involving different parameters.

Key words: LPG, Conventional LPG stove, burner, efficiency, emission

\section{INTRODUCTION}

Energy holds a vital importance in our lives. Thus, the ever reducing energy resources must be conserved in order to ensure the sustainable development. One of these forms of energy is employed in cooking i.e. LPG. The fuel of LPG finds very wide application in a large variety of domestic, industrial, commercial and leisure uses. A LPG cooking stove reported by Central Petroleum Research Association, India, in view of huge consumption of LPG in India, there is a need to look at different modifications for improving performance of the stove. Its consumption in domestic cooking is increasing every year at the rate of approximately $10 \%$. The total domestic consumption of LPG in India is almost comparable with other petroleum products used in industrial applications. A burner plays an important role in any combustion system as proper efficient modifications of a burner often lead to an efficient combustion and possibility to produce less pollutant formation. The Overall efficiency of stove depends upon different conditions such as temperature, pressure, wind speed, specific heat capacity of the vessel, overall shape of vessel, weight of vessel, and size of vessel.

\section{LITERATURE REVIEW}

Rahima and ljaz developed two improved cook stoves (one for biomass and one for natural gas) and studied on two parameters one was cooking vessel (round bottomed pot and flat bottomed pan) second was flow rate of gas (power) for natural gas cook stoves. They reported that pan gave higher efficiencies in all cooking stoves with regard to power (1). Pankaj and Salim uses water boiling test and emission test for investigating thermal efficiency and emissions (2). D.P. Mishra and Ranjit measured thermal efficiency of CNG burner for a wide range of parameters such as loading height, pot diameter, power level and loading weight (3). Ashman et al. reported a single production cooktop burner to determine the effects of loading height and thermal input on its efficiency and found that the thermal efficiency of the burner decreased with increasing loading height (4). In this study, we assess the effect of loading height on thermal efficiency, effect of pot diameter on thermal efficiency, effect of loading weight on thermal efficiency by using Water Boiling Test. Emissions level are also find out by using Emission Test.

\section{CONVENTIONAL DOMESTIC BURNER TECHNOLOGY}

Cooking stoves' burners are based on the principle of a Bunsen burner. The schematic diagram of a conventional LPG cooking stove's burner is shown in Fig. 1. Gas enters into the burner through a fixed orifice. Two ports are there for primary air supply. The position of these ports relative to gas entry may vary depending upon the design of the burner. There is a pipe shaped mixing tube with a narrow zone called throat. When the valve in gas line is opened, gas starts to flow into the 
tube, the velocity of gas increases at throat and low static pressure regions are formed into the tube due to which air from primary ports gets sucked. After the mixing of gas in the tube with air, gas start to come out in the form of jets through the small drilled holes at the burner head. These jets are so close that the flames from these jets merge to form a single flame. There is a secondary entry of air from bottom of mixing chamber and from the circumferential area surrounding the flame to combustion zone.

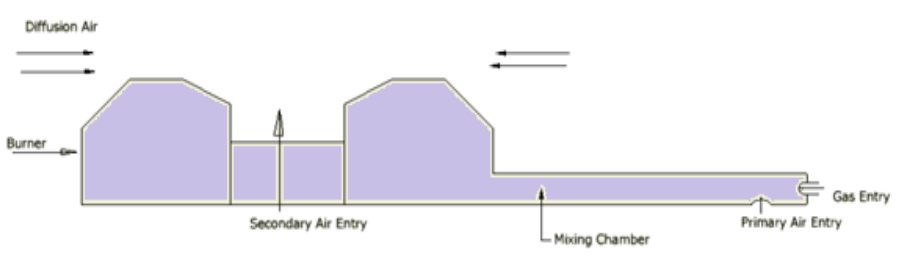

Fig. 1. Schematic diagram of a typical conventional LPG cooking stove burner.

\section{EXPERIMENTAL METHOD}

\section{A. Water Boiling Test for Calculating Thermal Efficiency}

In the present work, the thermal efficiencies of cooking stove were estimated by conducting the water boiling test as per the procedure given in IS 4246:2002 (Bureau of Indian Standards). A typical layout of set-up necessary for this test is shown in fig. 2 . The equipment for this test include a cylinder having $3 \mathrm{Kg}$ of LPG gas, digital weighing machine with least count of $0.1 \mathrm{gm}$, pressure gauge, pipe, pan, stirrer, stove burner and thermometer. The gas was passed for some time to attain uniform inlet pressure of $2.492 \mathrm{KN} / \mathrm{m}^{2}\left(30 \mathrm{gf} / \mathrm{cm}^{2}\right)$. Then the cylinder containing LPG gas was weighed. Further, the suitable pot (already weighed) was taken and filled with calculated amount of water and then weighed again. Then this pan was loaded on the burner at the center. Thermometer is used for measuring accurate temperature. Initial temperature of the water $\left(T_{1}\right)$ was noted. The gas control tap was then opened and the gas was ignited. The water was allowed to warm up to about $80^{\circ} \mathrm{C}$ when stirring is commenced and continued until the end of the test. The burner was put off when the temperature of water reaches $90^{\circ} \mathrm{C}$.

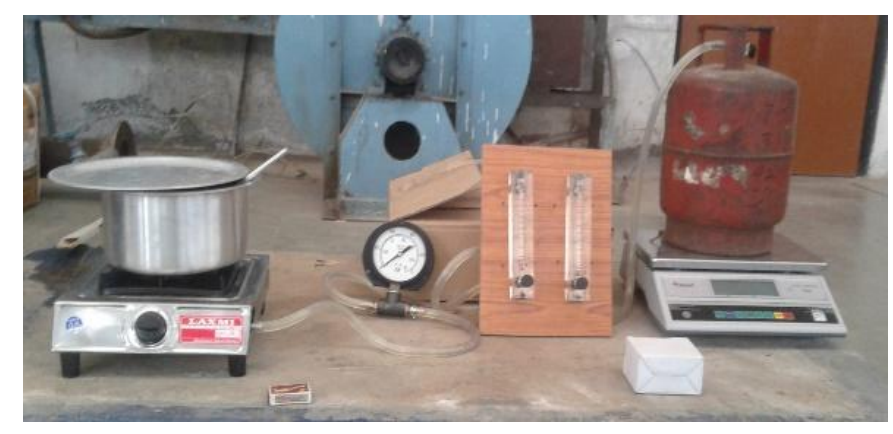

Fig. 2. Water Boiling Test Setup

Next, the valve on cylinder and stove was closed and the cylinder was disconnected and reweighed. Thus the mass of gas consumed in heating was calculated and the thermal efficiency was calculated by the following formula:

$$
E=100 C_{P}(G+W)\left(T_{2}-T_{1}\right) / M K
$$

Where

$E=$ thermal efficiency of the burner (\%),

$G=$ quantity of water in the vessel in $\mathrm{g}$,

$W=$ water equivalent of the vessel complete with stirrer and lid,

$T_{1} \& T_{2}=$ initial $\&$ final temperature of water in ${ }^{\circ} \mathrm{C}, \mathrm{C}_{\mathrm{P}}=$ Specific heat of water in $\mathrm{KJ} / \mathrm{Kg} \mathrm{K}$

$M=$ gas consumption in $\mathrm{g}$,

$K=$ Calorific Value of the gas in $\mathrm{KJ} / \mathrm{Kg}$. $(46100 \mathrm{KJ} / \mathrm{Kg})$

\section{Observations}

$M_{P}=$ Mass of Pot, $M_{L}=$ Mass of lid, $M_{S}=$ Mass of stirrer, $M_{w}=$ Mass of Water

$T_{1}=$ Initial temp of water, $T_{2}=$ Final temp of water

$\mathrm{C}_{P}$ of water $=4.18 \mathrm{KJ} / \mathrm{kg} \mathrm{K}$ 
Table 1. Effect of Pot Diameter $\left(M_{w}=1000 \mathrm{gm}, T_{1}=26^{\circ} \mathrm{C}, T_{2}=90{ }^{\circ} \mathrm{C}\right)$

\begin{tabular}{|c|c|c|c|c|c|c|c|}
\hline No. & $\begin{array}{c}\text { Dia. Of Pot } \\
\text { (inches) }\end{array}$ & $\begin{array}{c}\mathbf{M}_{\mathbf{P}}+\mathrm{M}_{\mathbf{L}}+\mathrm{M}_{\mathbf{S}} \\
\text { (grams) }\end{array}$ & Water Equivalent & $\begin{array}{c}\text { Total Mass } \\
\text { (grams) }\end{array}$ & $\begin{array}{c}\text { Initial wt. } \\
\text { of cylinder }\end{array}$ & $\begin{array}{c}\text { Final wt. } \\
\text { of cylinder }\end{array}$ & $\begin{array}{c}\text { Efficiency } \\
\text { (\%) }\end{array}$ \\
\hline 1 & 6 & 373.5 & 80.415 & 1080.415 & 8104.0 & 8090.4 & 46.10 \\
\hline 2 & 8 & 772.2 & 166.255 & 1166.255 & 8126.5 & 8113.0 & 50.13 \\
\hline 3 & 9.5 & 898.8 & 193.512 & 1193.512 & 8112.0 & 8100.0 & 57.72 \\
\hline
\end{tabular}

Table 2. Effect of Loading Height $\left(\mathrm{M}_{\mathrm{w}}=1000 \mathrm{gm}, \mathrm{T}_{1}=26^{\circ} \mathrm{C}, \mathrm{T}_{2}=90^{\circ} \mathrm{C}\right.$, Dia. of pot $=8$ Inches $)$

\begin{tabular}{|c|c|c|c|c|c|c|c|}
\hline No. & $\begin{array}{c}\text { Loading height } \\
\text { (cm) }\end{array}$ & $\begin{array}{c}\mathbf{M}_{\mathbf{P}}+\mathbf{M}_{\mathbf{L}}+\mathbf{M}_{\mathbf{s}} \\
\text { (grams) }\end{array}$ & $\begin{array}{c}\text { Water } \\
\text { Equivalent }\end{array}$ & $\begin{array}{c}\text { Total Mass } \\
\text { (grams) }\end{array}$ & $\begin{array}{c}\text { Initial wt. } \\
\text { of cylinder }\end{array}$ & $\begin{array}{c}\text { Final wt. } \\
\text { of cylinder }\end{array}$ & $\begin{array}{c}\text { Efficiency } \\
\text { (\%) }\end{array}$ \\
\hline 1 & 1.6 & 772.2 & 166.255 & 1166.255 & 8012.8 & 7998.0 & 45.79 \\
\hline 2 & 2.4 & 772.2 & 166.255 & 1166.255 & 8126.5 & 8113.0 & 50.13 \\
\hline 3 & 4.6 & 772.2 & 166.255 & 1166.255 & 8027.0 & 8011.5 & 43.66 \\
\hline
\end{tabular}

Table 3. Effect of Loading Weight $\left(T_{1}=26^{\circ} \mathrm{C}, T_{2}=90^{\circ} \mathrm{C}\right.$, Dia. of pot $=8$ Inches $)$

\begin{tabular}{|c|c|c|c|c|c|c|c|}
\hline No. & $\begin{array}{c}\text { Mass of water } \\
\left(\mathbf{M}_{\mathbf{w}}\right)\end{array}$ & $\begin{array}{c}\mathbf{M}_{\mathbf{P}}+\mathbf{M}_{\mathbf{L}}+\mathbf{M}_{\mathbf{s}} \\
\text { (grams) }\end{array}$ & $\begin{array}{c}\text { Water } \\
\text { Equivalent }\end{array}$ & $\begin{array}{c}\text { Total Mass } \\
\text { (grams) }\end{array}$ & $\begin{array}{c}\text { Initial wt. } \\
\text { of cylinder }\end{array}$ & $\begin{array}{c}\text { Final wt. } \\
\text { of cylinder }\end{array}$ & $\begin{array}{c}\text { Efficiency } \\
\text { (\%) }\end{array}$ \\
\hline 1 & 1000 & 772.2 & 166.255 & 1166.255 & 8126.5 & 8113.0 & 50.13 \\
\hline 2 & 2000 & 772.2 & 166.255 & 2166.255 & 8080.0 & 8057.3 & 55.37 \\
\hline 3 & 3000 & 772.2 & 166.255 & 3166.255 & 8057.0 & 8027.2 & 61.66 \\
\hline
\end{tabular}

\section{B. Emission Test for Exhaust Gas Analysis}

Emission test was performed in accordance to standards and guidelines of IS: 4246:2002. There were two additional equipment employed. One was the collecting hood and other was the Exhaust gas analyzer. Gas was admitted at inlet pressure of $2.943 \mathrm{KN} / \mathrm{m}^{2}$ .Before taking readings, 8 inches pot with sufficient water was put on the burner and the burner was allowed to preheat for 5 minutes since at the time of warming up $\mathrm{CO}$ content may be high. Then the pot was unloaded and hood is placed over the burner as shown in fig. 3. The hood was having converging cone shape and a protruding pipe shape end to collect the emissions. The hood was fabricated in such a way that it should not interfere the normal combustion. The emissions from the pipe end of hood, enters into the exhaust gas analyzer through a long flexible pipe. The readings of emissions are obtained by using the exhaust gas analyzer at different power levels. The exhaust gas analyzer as shown in fig. 4 is an automatic machine calibrated to measure the level of emissions originating as a result of combustion.

Table 4. Emission Test

\begin{tabular}{|c|l|c|c|c|}
\hline No. & Parameter & $\begin{array}{c}\text { High } \\
\text { Power }\end{array}$ & $\begin{array}{c}\text { Medium } \\
\text { Power }\end{array}$ & $\begin{array}{c}\text { Low } \\
\text { Power }\end{array}$ \\
\hline 1 & $\mathrm{O}_{2}(\%)$ & 6.23 & 9.78 & 12.26 \\
\hline 2 & $\mathrm{CO}(\mathrm{ppm})$ & 1 & 0 & 13 \\
\hline 3 & $\mathrm{NO}(\mathrm{ppm})$ & 49 & 41 & 24 \\
\hline 4 & $\mathrm{NO}(\mathrm{ppm})$ & 47 & 39 & 23 \\
\hline 5 & $\mathrm{HC}(\mathrm{ppm})$ & 84 & 66.2 & 54.5 \\
\hline 6 & $\mathrm{SO}_{2}(\mathrm{ppm})$ & 0 & 0 & 0 \\
\hline 7 & $\mathrm{CO}_{2}(\%)$ & 2.88 & 2.19 & 1.7 \\
\hline 8 & $\mathrm{F.T}\left({ }^{\circ} \mathrm{C}\right)$ & 52.5 & 74.3 & 85 \\
\hline 9 & $\begin{array}{l}\text { Efficiency } \\
(\%)\end{array}$ & 96 & 90.3 & 88.7 \\
\hline
\end{tabular}




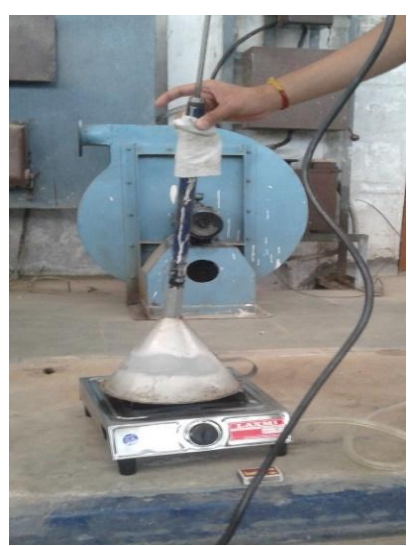

Fig. 3. Emission Test Setup

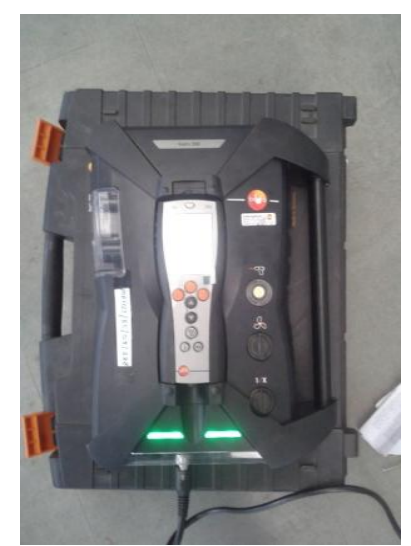

Fig. 4. Exhaust Gas Analyzer

\section{V.RESULTS AND DISCUSSIONS}

\section{A. Effect of Pot Diameter}

It was observed that the thermal efficiency of pot having largest diameter is maximum as there is more transfer of heat from burner to pot due to larger surface area. Thus thermal efficiency increases with increase in pot diameter.

\section{B. Effect of Loading Height}

The vertical distance between pot base and burner head is called the Loading Height. It was observed that when the loading height was too low, then the combustion was incomplete due to which heat generated and heat transferred was less and so the thermal efficiency was less. When the loading height was high then loss of heat to surrounding was increased and so the thermal efficiency was less. Maximum efficiency was achieved at an optimum height.

\section{C.Effect of Loading Weight}

It was observed that as the loading weight increases there is an increase in thermal efficiency due to increase in heat absorbed by the vessel at the lateral surface. Maximum thermal efficiency of about $61.66 \%$ was achieved. Thus thermal efficiency increases with loading weight.

\section{Effect of Power Level on Emission}

The main constituent of exhaust gas emission from the LPG air flames are $\mathrm{CO}_{2}, \mathrm{HC}, \mathrm{NO}$ and $\mathrm{NO}$. The intermediate product $\mathrm{CO}$ is more likely to be converted to the $\mathrm{CO}_{2}$ provided enough oxygen is available at relatively high temperature. It was found that with increase in power level $\mathrm{CO}_{2}$ emission increases. This is due to the increase of fuel rate leading to higher carbon conversion at higher power level. Also, NOx emission increases due to the higher temperature of the flue gases caused by higher heat releases rate at higher power level. Hence in the present study an attempt is made to analyze the emission covering $\mathrm{CO}_{2}$ and $\mathrm{NO}$ from diffusion flame. It was also found that the unburnt hydrocarbon emission also increases with the power level.

The present work has shown the possibility of saving energy by doing more work on areas like providing good insulated materials for conservation of heat below nearer to pot, to optimize fuel combustion rate means maintaining air fuel ratio and to minimize heat losses.



Fig. 5. Effect of Pot Diameter on Thermal Efficiency



Fig. 6. Effect of Loading Height on Thermal Efficiency 


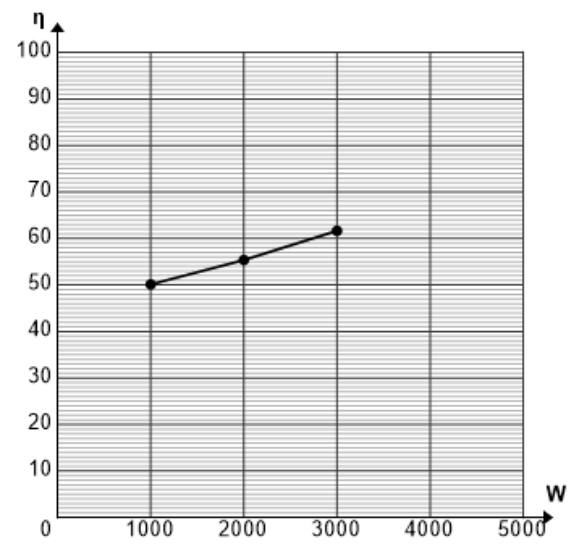

Fig. 7. Effect of Loading Weight on Thermal Efficiency

\section{CONCLUSION}

A novel LPG burner is designed developed and studied by carrying out series of experiments. In the initial phase an extensive study is carried to design the burner by a varying several parameters. The effects of loading height, Pot diameter, and loading weight on the thermal efficiency of LPG burner is investigated for a wide range of operating conditions. The present study reveals that pot size and power level were found to have large effects on the thermal efficiency and emission for this LPG burner. Maximum Thermal efficiency of $61.66 \%$ could be achieved with the present burner. The maximum $\mathrm{NO} x$ emission level for this burner is around $49 \mathrm{ppm}$. It can be concluded from these studies that there is a great scope for improving the efficiency of LPG gas system with the use of well-designed burner using flat bottom pots, operating close to the power level at which highest efficiency is obtained.

\section{ACKNOWLEDGEMENT}

First of all, we would like to acknowledge Dr. Rajesh Gupta (Associate Professor, MANIT Bhopal) for his guidance and support. The success of the work would not have been possible without him. Secondly, we are grateful to Dr. Appu Kuttan KK (the Director of MANIT Bhopal) for encouraging students towards the research work. We are grateful to the Mechanical Department faculties and the lab officials for their support and help. Last but not the least, the organizers of IC IMPACT 2014, as they have provided us a great platform to show our work.

\section{REFERENCES}

[1] Rahima Akter Lucky and ljaz Hossain, Efficiency study of Bangladeshi cook stoves with an emphasis on gas cook stoves, Energy 26(3) (2001), 221-237.

[2] Pankaj P. Gohil, and Salim A. Channiwala Experimental investigation of performance of conventional LPG cooking stove (2011)

[3] D.P. Mishra and Ranjeet Singh, Efficiency and emission of CNG fuelled Domestic Swirl Chamber (2013).

[4] P.J. Ashman, R. Junus, J.F. Stubington, G.D Sergeant, The effects of load height on the emissions from a natural gasfired domestic cooktop burner, Combustion Science \& Technology 103 (1994) 283-298

[5] IS 4246:2002 Indian Standard Domestic Gas Stove for Use With Liquefied Petroleum Gases-Specification (Fifth Revision)

[6] Usa Makmool, Sumrerng Jugjai, Suvit Tia, Pumyos Vallikul and Bundit Fungtammasan, Application of particle image velocimetry to analyse thermal performance of LPG cooking burners, As. J. Energy Env. 08(04) (2007), 635-644.

[7] P. Muthukumar, Piyush Anand and Prateek Sachdeva, Performance analysis of porous radiant burners used in LPG cooking stove, International Journal of Energy and Environment 2(2) (2011), 367-374. 